\title{
EDITORIAL
}

\section{TRABALHO, DISCRIMINAÇÃO E PRECARIZAÇÃO NO SÉCULO XXI}

O ano de 2020 iniciou e terminou sob o signo da crise econômica, social, política e de saúde. Ano difícil que exigiu dos diversos agentes políticos uma reflexão continua em busca de soluções ou pelo menos de elementos mitigadores para a crise generalizada. $\mathrm{O}$ ano se encerra com quase 200 mil mortes, milhões de infectados e desempregados, aumento de preços, queda dos rendimentos dos trabalhadores e da classe média em meio ao aumento da fortuna dos bilionários. Fato comum ao continente americano que expressa as desigualdades do sistema capitalista de produção.

A RERUT encerra o ano com sete artigos diversificados, expressivos da riqueza acadêmica inerente as ciências econômicas. Nesse número final de 2020, encontramos no artigo de abertura da revista um estudo que procurou analisar o comportamento do orçamento municipal da cidade de Carnaubais/RN. Na busca de realizar tal intento, partiu-se dos conceitos de consumo e despesas sociais do modelo de James O`Connor, no período de 2001/2018, utilizando-se uma metodologia que partiu de uma revisão de literatura relacionada com os fundamentos teóricos do modelo de O`Connor e estatísticas descritivas para mensurar o comportamento orçamentário de Carnaubais/RN. Os resultados mostraram que o consumo social revelou significativa predominância, comparativamente às despesas sociais, apontando convergência do modelo de O`Connor e o teste empírico realizado.

Algumas contribuições de John Maynard Keynes são apresentadas no segundo artigo. Essas contribuições apresentadas auxiliam na compreensão do sistema capitalista. O artigo proporciona uma explicação sucinta sob a relação dos fatores para tomadas de decisões dos capitalistas e suas influências na hierarquia das decisões da economia e as reformas sociais propostas por Keynes. Os autores encerram o artigo mostrando a valorização dos estudos de Keynes e a introdução da crítica do economista Minsky sobre o Keynesianismo convencional, a sua fragilidade financeira e a argumentação que para Keynes a economia capitalista era composta por ativos. 
O processo de desestruturação do mercado de trabalho brasileiro tem culminado em elevadas taxas de desemprego e precarização das relações trabalhistas, conforme atestam dados recentes do IBGE. O terceiro artigo terce considerações acerca da informalidade no Brasil, com enfoque no trabalho digital precarizado dos entregadores por aplicativos, visto que se configuram como um dos grupos sociais com maior exposição às condições precarizadas de trabalho. Os resultados do artigo apontam que há indicativos de intensa jornada de trabalho, baixa remuneração, baixa proteção social e falta de autonomia no gerenciamento da força de trabalho. O estudo analisou ainda, como o fenômeno da terceirização e do trabalho autônomo dialogam com a precarização deste tipo de trabalho e as possibilidades de novas organizações laborais, dentro da legislação trabalhista brasileira.

Com as alterações ocorridas no Sistema Monetário Internacional (SMI) com a quebra do regime de Bretton Woods em 1960/1970, abre-se uma discussão sobre a relevância do SMI atual para uma abordagem da a relação centro-periferia. No atual regime monetária internacional, denominado de Dólar Flexível, se apresenta como uma dimensão especial para analisar a relação centro-periferia a partir da hierarquia de moedas. Essa hierarquia é baseada pela liquidez das moedas em âmbito internacional e se estrutura a partir do dólar no núcleo do sistema, seguida pelo o euro, entre outras moedas centrais e na base desse sistema estão as moedas periféricas. Hierarquia que se apresenta como problemática para os países de moedas periféricas, particularmente, quanto as vulnerabilidades, tais como: tendência de instabilidades na taxa de câmbio e taxa de juros e tendência especulativa, dentre outras. Nesse sentido, o quarto artigo analisa, para o Brasil, a posição periférica de sua moeda, no regime dólar flexível, no período 2000-2017, particularmente, quanto ao perfil dos fluxos de capitais.

O quinto artigo abordar os aspectos estruturais sob os quais o espaço econômico do Rio Grande do Norte adentra na nova conjuntura de crise, especialmente no que tange aos problemas e limitações de ação do governo estadual. Para realizar tal intento, demonstrou-se que se acumulam elementos regressivos historicamente, e após um período de crescimento considerável, as novas crises possuem alto potencial destrutivo dos ganhos econômicos auferidos. Um outro aspecto importante relaciona-se ao fato de que o contexto federativo e os problemas das instituições de estado local, materializados na questão financeira, engessam a possibilidade de iniciativas locais para combater a crise. Por fim, os autores concluem 
que sem a intervenção e coordenação do Estado Nacional, de forma efetiva, não será possível visualizar um horizonte diferente se não o de crise generalizada.

A economia criativa no mercado da moda é o tema do sexto artigo. Procurando identificar a influência econômica da economia criativa no mercado da moda no desenvolvimento da indústria têxtil na região nordeste, os autores mostraram como o mercado têxtil Nordestino é um dos principais setores econômicos da região gerando produto e renda para seus residentes. Além disso, mostram que a modernização ocorrida no setor ocorreu tardiamente, mas vem crescendo e se inovando em tecnologia, sendo considerada a segunda região têxtil mais importante do país.

O último artigo utilizou-se de uma abordagem quali-quantitativa com o objetivo de aplicar os indicadores de localização e especialização e analisar as mudanças na distribuição dos vínculos empregatícios nos setores econômicos e na estrutura produtiva nos municípios da microrregião de Montes Claros entre 2013 a 2014. Os resultados encontrados demonstraram que na microrregião de Montes Claros os municípios de Montes Claros/MG e Juramento/MG se destacaram no setor industrial e no setor agropecuário o destaque é do município de Verdelândia/MG. Já no setor de Construção Civil pode-se destacar os municípios de Montes Claros/MG, Ponto Chique/MG, Brasília de Minas/MG e Ubaí/MG. A maior estrutura espacial da microrregião é a do município de Montes Claros/MG. As atividades desenvolvidas nos setores de Serviços, Comércio, Indústria e Construção Civil foram distribuídas de forma igualitária na microrregião de Montes Claros.

Desejamos aos leitores uma excelente leitura e um ano de 2021 melhor do que o ano que se encerrou. 